\title{
FAKTOR-FAKTOR YANG MEMPENGARUHI MOTIVASI WANITA UNTUK BERWIRAUSAHA DI KABUPATEN PASAMAN BARAT
}

\author{
Fitria Devi, Lovelly Dwinda Dahen, Jimi Ronald \\ Program Studi Pendidikan Ekonomi STKIP PGRI Sumatera Barat \\ Fitriadevi232@gmail.com
}

\begin{abstract}
This study aims to find out the influence of the influence of husband's role on women's motivation for entrepreneurship, the source of capital on women's motivation for entrepreneurship, self-empowerment of women's motivation for entrepreneurship, education on women's motivation for entrepreneurship and interest in women's motivation for entrepreneurship, influence of husband role, source of capital, self-empowerment, education, interest and motivation jointly influence women's motivation for entrepreneurship in West Pasaman. This type of research is descriptive associative research, the population in this study is women in West Pasaman as many as 440 people with a sample of this study is as many as 50 people using total sampling techniques. Instruments used for research in the form of open and closed questionnaires. Data analysis techniques are descriptive analysis and inductive analysis. The results of this study showed that: 1) The role of husbands has a significant effect on women's motivation to be entrepreneurial with a regression coefficient of 0.235 . The coefficient value is significant because the thitung value is 3,650> ttabel is 2.0141. 2) the source of capital has no significant effect on the motivation of women to be entrepreneurial where at the value of $\mathrm{x} 2$ loglikelihood ratio which shows $\mathrm{x} 2$ count $<\mathrm{x} 2$ tabel thus means receiving $\mathrm{HO}$ which means receiving eliminating the capital source variable (x2). 3) self-empowerment has a significant effect on women's motivation to be entrepreneurial with a regression coefficient value of 0.464 . The coefficient value is significant because the thitung value is 4,069 > ttabel of 2.0141. 4) Education has no significant effect on women's motivation to be entrepreneurial with the value of $\mathrm{x} 2$ calculate likelihood ratio which shows $\mathrm{x} 2$ count $<\mathrm{x} 2$ tabel thus means receiving $\mathrm{HO}$ which thus accepting eliminates educational variables (x4). 5) interest has a significant effect on women's motivation to be entrepreneurial with a regression coefficient value of 0.308 . thitung of 3,254 > ttabel of 2.0141. The role of husband, source of capital, self-empowerment, education and interest in women's motivation for entrepreneurship where obtained A value of FCalculated 25,350> FTabel 2.40 means Ho reject Ha accepted.
\end{abstract}

Key words: Influence of husband's role, source of capital, self-empowerment, education and interest in women's motivation for entrepreneurship 


\section{PENDAHULUAN}

Wanita yang jumlahnya hampir separuh penduduk laki-laki merupakan sumber daya yang sangat potensial bagi peningkatan ekonomi. Pada umumnya banyak wanita yang bekerja karena keharusan pemenuhan kebutuhan keluarga selain itu, untuk otonomi keuangan yang tidak selalu bergantung pada pendapatan suami. Usaha mandiri yang biasanya dikerjakan wanita terutama yang menjalankan peran ganda adalah berdagang, jasa, dan bidang lain yang ditekuni. Faktanya, pendapatan yang diperoleh cenderung rendah karena keterbatasan dan kemampuan khusus untuk mengelola.

Fenomena yang terjadi dalam masyarakat adalah semakin banyaknya wanita membantu suami mencari tambahan penghasilan keluarga. Dimana peran wanita tidak hanya sebagai ibu rumah tangga namum ia juga berperan sebagai pencari nafkah untuk meningkatkan kesejahteraan keluarga.
Wanita yang berwirausaha memiliki peluang yang sama juga untuk dapat berhasil. Menurut pernyataan Menteri Koperasi dan UKM, peran wanita yang berwirausaha sangat penting dalam peningkatan kesejahteraan keluarga di Indonesia. Di Pasaman Barat persaingan dalam pasar bebas saat ini memberikan peluang seluas luasnya bagi siapapun termasuk wanita, dimana nanti akan bida berwirausaha pada bidang apa saja seperti fashion, makanan, bagian jasa dan lainnya. Namun hal ini memerlukan potensi yang berkualitas dari masing-masing individu untuk menjalankan usahanya. Sebagai salah satu cara bertahan dan berkembang adalah berusaha sendiri

Menurut Alma (2001:64) motivasi didefinisikan sebagai kemauan untuk berbuat sesuatu, dan tergantung pada kekuatan motifnya. Sumadi Suryabrata (Djaali H, 2013: 101) motivasi adalah keadaan yang terdapat dalam diri seseorang untuk 
melakukan aktivitas tertentu guna pencapaian suatu tujuan.

Menurut Pristiana et al (2009:43) faktor-faktor yang mempengaruhi motivasi wanita rumah tangga memutuskan berwirausaha disebabkan oleh faktor internal yang berasal dari dalam diri individu dan faktor eksternal yang berasal dari luar individu sehingga membuat wanita rumah tangga mengambil keputusan peran produktifnya sebagai wirausaha. Faktor internal yaitu minat, pemberdayaan diri, motivasi dan faktor eksternal yaitu peran suami dan sumber modal.

"Women hold-up half the sky", merupakan suatu pepatah yang ingin mengungkapkan konsep dasar seberapa besar tempat wanita dalam pembangunan (Ptistiana, dalam Leidenfrost 1992:109). Ungkapan ini muncul karena wanita pada dasarnya menduduki setengah bahkan lebih dari populasi penduduk dunia dan mereka mempunyai peran penting yang sama dengan kaum pria yaitu dalam menciptakan kehidupan yang lebih baik bagi keluarga, selain itu antara pria dan wanita sebenarnya merupakan mitra yang sejajar.

Menurut (Sarosa 2003) sumber modal dapat diperoleh tiga cara yaitu: modal sendiri, meminjam, dan kerja sama dengan pihak lain. Sumber modal sendiri dapat berasal dari warisan, tabungan

Pemberdayaan diri berarti kekuatan untuk melakukan sesuatu yang berasal dari pengetahuan baru, keterampilan yang dimiliki, maupun pengalaman yang diperoleh.

Dengan diperolehnya pendidikan yang tinggi, akan meningkat pula kemampuan dan keterampilan yang dimilikinya. Seseorang yang memiliki pendidikan tinggi cenderung memperoleh penghasilan yang lebih tinggi dibandingkan dengan seseorang yang memiliki pendidikan rendah. Pendidikan akan memberikan bekal pengetahuan yang dibutuhkan dalam mengelola usaha, terutama ketika menghadapi suatu permasalahan. Individu yang tidak mengeyam pendidikan formal namun ia bisa belajar dari pengalaman dan 
HORIZON

PENDIDIKAN
JURNAL HORIZON PENDIDIKAN

Publish by: Library of STKIP PGRI Sumatera Barat

E-ISSN : 2775-5770

Vol. 1 No. 2 (Mei 2021) (333-344) dari orang lain pun bisa meningkatkan kewirausahaan yang dimiliki.

Minat yang dimaksudkan adalah kecenderungan yang tinggi dari seseorang untuk melakukan aktivitas tertentu yang disukai, didasari bakat yang dimiliki, pengalaman dan pada akhirnya mendorong seseorang untuk mengambil keputusan berwirausaha.

\section{METODE PENELITIAN}

Sesuai dengan identifikasi masalah, perumusasn, dan tujuan penelitian, maka penelitian ini tergolong penelitian asosiatif dengan pendekatan kuantitatif, karena penelitian ini menerangkan suatu gejala, peristiwa atau kejadian yang telah terjadi, serta menentukan ada atau tidaknya pengaruh suatu variabel bebas terhadap variabel terikat dimana hasil penelitian ini dinyatakan dalam bentuk angka. Menurut Arikunto (2010) penelitian deskriptif adalah penelitian yang dimaksudkan untuk mengumpulkan informasi mengenai status suatu gejala yang ada, yaitu keadaan gejala menurut apa adanya pada saat penelitian dilakukan. Penelitian Asosiatif menurut Sangadji (2010) adalah penelitian yang bertujuan untuk menemukan ada atau tidaknya hubungan atau pengaruh antara variabel yang satu dengan variabel yang lainnya dan penelitian kuantitatif adalah penelitian yang datanya dinyatakan dalam angka dan dianalisis dengan teknik statistic.

Penelitian ini dilaksanakan pada bulan Januari tahun 2021. Penelitian ini akan dilakukan di Kabupaten Pasaman Barat Provinsi Sumatera Barat.

Populasi menurut Arikunto, (2010:173) adalah keseluruhan subjek penelitian.Adapun populasi dalam penelitian ini sebanyak 440 orang adalah wanita dengan usia produktif yang menjalankan kegiatan berwirausaha di Kabupaten Pasaman Barat .

Sampel menurut Arikunto (2010:174) adalah sebahagian atau wakil populasi yang diteliti. Sedangkan menurut Sugiyono 
PENDIDIKAN
JURNAL HORIZON PENDIDIKAN

Publish by: Library of STKIP PGRI Sumatera Barat

E-ISSN : 2775-5770

Vol. 1 No. 2 (Mei 2021) (333-344)
(2014:62) sampel adalah bagian dari jumlah dan karakteristik yang dimiliki oleh populasi.

Teknik pengambilan sampel dalam penelitian ini adalah total sampling dimana keseluruhan populasi di jadikan sampel. Maka sampel dalam penelitian ini adalah sebanyak 50 orang.

Teknik analisis data dengan menggunakan analisis deskriptif dan analisis induktif. Statistik deskriptif adalah statistik yang digunakan untuk menganalisis data dengan cara mendeskripsikan atau menggambarkan data yang telah terkumpul sebagaimana adanya tanpa bermaksud membuat kesimpulan yang berlaku untuk umum atau generalisasi. Uji induktif ini bertujuan untuk melihat pengaruh masing-masing variabel bebas terhadap variabel terikat analisis yang digunakan adalah regresi berganda, analisis ini digunakan untuk mengetahui kontribusi masingmasing variable terhadap variabel lainnya.

\section{HASIL DAN PEMBAHASAN}

Adapun hasil uji Analisi Linear Beganda dengan menggunakan bantuan program SPSS versi 16.0 dan eviews maka diperoleh data sebagai berikut

Tabel 1. Hasil Analisis Regresi Linear Berganda Secara Keseluruhan

\begin{tabular}{lrrrrr}
\hline Model & B & Std.Error & Beta & T & Sig. \\
\hline 1 (Constant) & -2.109 & 3.509 & & -.601 & .551 \\
Peran suami & .235 & .064 & .365 & 3.650 & .001 \\
pemberdayaan diri & .464 & .114 & .389 & 4.069 & .000 \\
$\quad$ minat & .308 & .095 & .341 & 3.254 & .002
\end{tabular}

Sumber: Olahan Data Primer, 2020 


\section{JURNAL \\ HORIZON}

PENDIDIKAN
JURNAL HORIZON PENDIDIKAN

Publish by: Library of STKIP PGRI Sumatera Barat

E-ISSN : 2775-5770

Vol. 1 No. 2 (Mei 2021) (333-344)
Model persamaan regresi linier

berganda yang dapat ditulis dari hasil

tersebut sebagai berikut:

$\mathrm{Y}=\mathrm{a}+\mathrm{b}_{1} \mathrm{X}_{1}+\mathrm{b}_{3} \mathrm{X}_{3}+\mathrm{b}_{5} \mathrm{X}_{5}$

$Y=-2,109+0,235 X_{1}+0,464 X_{3}+$

$0,308 \mathrm{X}_{5}$

Nilai konstanta sebesar -2,109 berarti tanpa adanya pengaruh dari variabel bebas maka nilai variabel terikat hanya sebesar -2109.Koefisien regresi variabel peran suami $\left(\mathrm{X}_{1}\right)$ sebesar 0,235 yang bertanda positif, koefisien regresi variabel pemberdayaan diri $\left(\mathrm{X}_{3}\right)$ sebesar 0,464 yang bertanda positif, koefisien regresi variabel minat $\left(\mathrm{X}_{5}\right)$ sebesar 0,308. Hal ini berarti adanya pengaruh positif.

1. Pengaruh Peran Suami Terhadap Motivasi Wanita Untuk

Berwirausaha di Kabupaten Pasaman Barat

Hasil penelitian ini sejalan dengan penelitian sebelumnya yang dilakukan oleh Rizal M, (2016) tentang faktor-faktor yang mempengaruhi wanita berwirausaha (studi kasus di Kota Langsa). Peran suami adalah dukungan suami terhadap aktivitas perempuan entrepreneur yang akomodatif, baik dalam bentuk bantuan modal maupun kebebasan kesempatan yang diberikan untuk perempuan menjalanakan usahanya di luar rumah (produktif).

Hasil penelitian di temukan peran suami berpengaruh signifikan terhadap motivasi wanita untuk berwirausaha di Kabupaten Pasaman Barat. Hal ini dibuktikan dengan penelitian yang menyatakan bahwa nilai $t_{\text {hitung }}$ sebesar $3,650>\quad t_{\text {tabel }}$ sebesar 2,0141 dengan nilai signifikan $0,001<\mathrm{a}=0,05$, berarti $\mathrm{H}_{\mathrm{a}}$ diterima dan $\mathrm{H}_{\mathrm{o}}$ ditolak. Koefisien regresi menunjukan bahwa motivasi wanita untuk berwirausaha di Kabupaten Pasaman Barat meningkat sebesar 0,235 dalam setiap satuan peran suami meningkat sebesar satu satuan sedangkan variabel bebas lain tetap.

Jadi dapat disimpulkan bahwa peran suami berpengaruh terhadap motivasi wanita untuk berwirausaha.

2. Pengaruh Sumber modal Terhadap Motivasi Wanita Untuk 
Berwirausaha di Kabupaten Pasaman

Barat

Hasil penelitian di temukan sumber modal tidak berpengaruh terhadap motivasi wanita untuk berwirausaha di Kabupaten Pasaman Barat. Dimana pada loglikelihood ratio sebesar 0.563703 sedangkan nilai $\mathrm{x}^{2}$ tabel adalah sebesar 3,841, dengan a =0,05 dengan df 1 (sebesar variabel yang dihilangkan) dimana menunjukan $\mathrm{x}^{2}$ hitung $<\mathrm{x}_{\text {tabel }}^{2}$ dengan demikian berarti menerima $\mathrm{H}_{\mathrm{O}}$ yang berati menerima menghilangkan variabel sumber modal (x2).

Jadi dapat disimpulkan berdasarkan hasil penelitian yang dilakukan di Pasaman Barat sumber modal tidak berpengaruh signifikan terhadap motivasi wanita untuk berwirausaha di Kabupaten Pasaman Barat.

3. Pengaruh Pemberdayaan Diri Terhadap Motivasi Wanita Untuk Berwirausaha di Kabupaten Pasaman Barat

Hasil penelitian ini sejalan dengan penelitian sebelumnya yang dilakukan oleh Relawati, (2011:71) wanita yang terlibat aktif dalam wirausaha misalnya, mempunyai kesempatan luas untuk memberdayakan diri. Pemberdayaan diri ini terjadi karena peningkatan kemampuan financial maupun karena aktivitas yang dilakukan yang menuntut mereka harus bekerja, berfikir dan mengambil keputusan.

Hasil penelitian di temukan pemberdayaan diri berpengaruh signifikan terhadap motivasi wanita untuk berwirausaha di Kabupaten Pasaman Barat nilai nilai $t_{\text {hitung }}$ sebesar 4,069 > $t_{\text {tabel }}$ sebesar 2,0141 dengan nilai signifikan $0,000 \mathrm{a}=$ 0,05, berarti $\mathrm{H}_{\mathrm{a}}$ diterima dan $\mathrm{H}_{\mathrm{o}}$ ditolak. Koefisien regresi menunjukan bahwa motivasi wanita untuk berwirausaha di Kabupaten Pasaman Barat meningkat sebesar 0,464 dalam setiap satuan, jika pemberdayaan diri meningkat sebesar satu satuan sedangkan variabel bebas lain tetap.

Jadi dapat disimpulkan berdasarkan hasil penelitian yang dilakukan di Pasaman Barat 
JURNAL HORIZON PENDIDIKAN

PENDIDIKAN

Publish by: Library of STKIP PGRI Sumatera Barat

E-ISSN : 2775-5770

Vol. 1 No. 2 (Mei 2021) (333-344)

http://ejournal.stkip-pgri-sumbar.ac.id/index.php/horizon

pemberdayaan diri berpengaruh terhadap motivasi wanita untuk berwirausaha di Kabupaten Pasaman Barat.

4. Pengaruh Pendidikan Terhadap Motivasi Wanita Untuk Berwirausaha di Kabupaten Pasaman Barat

Pendidikan tidak berpengaruh signifikan terhadap motivasi wanita untuk berwirausaha di Kabupaten Pasaman Barat, nilai dari $\mathrm{x}^{2}$ hitung likelihood ratio adalah sebesar 0.312201 sedangkan nilai $\mathrm{x}^{2}$ tabel adalah sebesar 3,841, dengan a $=0,05$ dengan df 1 (sebesar variabel yang dihilangkan) dimana menunjukan $\mathrm{x}^{2}{ }_{\text {hitung }}<\mathrm{x}_{\text {tabel }}^{2}$ dengan demikian berarti menerima $\mathrm{H}_{\mathrm{O}}$ yang berati menerima menghilangkan variabel pendidikan.

Jadi dapat disimpulkan berdasarkan hasil penelitian yang dilakukan di Pasaman Barat pendidikan tidak berpengaruh signifikan terhadap motivasi wanita untuk berwirausaha di Kabupaten Pasaman Barat.
5. Pengaruh Minat Terhadap Motivasi Wanita Untuk Berwirausaha di Kabupaten Pasaman Barat

Hasil penelitian di temukan minat berpengaruh signifikan motivasi wanita untuk berwirausaha di Kabupaten Pasaman Barat, nilai $t_{\text {hitung }}$ sebesar $3,254>t_{\text {tabel }}$ sebesar 2,0141 dengan nilai signifikan $0,002<a=0,05$, berarti $\mathrm{H}_{\mathrm{a}}$ diterima dan $\mathrm{H}_{\mathrm{o}}$ ditolak. Koefisien regresi menunjukan bahwa motivasi wanita untuk berwirausaha di Kabupaten Pasaman Barat meningkat sebesar 0,308 dalam setiap satuan jika lingkungan tempat tinggal meningkat sebesar satu satuan sedangkan variabel bebas lain tetap. Jadi dapat disimpulkan berdasarkan hasil penelitian yang dilakukan di Pasaman Barat minat berpengaruh terhadap motivasi wanita untuk berwirausaha di Kabupaten Pasaman Barat.

6. Pengaruh Peran Suami, Pemberdayaan diri, dan Minat Terhadap Motivasi Wanita Untuk 
PENDIDIKAN
JURNAL HORIZON PENDIDIKAN

Publish by: Library of STKIP PGRI Sumatera Barat

E-ISSN : 2775-5770

Vol. 1 No. 2 (Mei 2021) (333-344)
Berwirausaha di Kabupaten

Pasaman Barat

Berdasarkan hasil uji hipotesis yang dilakukan secara bersamasama ditemukan bahwa variabel peran suami, pemberdayaan diri, dan minat terhadap motivasi wanita untuk berwirausaha di kabupaten pasaman barat.

Analisis data dan pengujian hipotesis yang telah dilakukan untuk secara keseluruhan diperoleh nilai $\mathrm{F}_{\text {Hitung }} 25,350>\mathrm{F}_{\text {Tabel }} 2,40$ dan nilai signifikan $0,000<=0,05$. Hal ini berarti $\mathrm{H}_{0}$ ditolak dan $\mathrm{H}_{\mathrm{a}}$ diterima berarti secara bersama-sama berpengaruh variabel independent terhadap variabel dependent. koefisien determinasi yang dilakukan diperoleh nilai diperoleh nilai $R_{\text {squere }}$ sebesar 0,623 yang artinya $62,3 \%$.

Dengan demikian dapat dikatakan bahwa peran suami, pemberdayaan diri, dan minat berpengaruh terhadap motivasi wanita untuk berwirausaha di kabupaten pasaman barat.

\section{KESIMPULAN}

Peran suami berpengaruh positif dan signifikan terhadap motivasi wanita untuk berwirausaha di Kabupaten Pasaman Barat, hal ini dibuktikan dengan nilai Koefisien regresi sebesar 0,235 apabila nilai variabel peran suami meningkat sebesar satu satuan maka peran suami akan meningkat sebesar 0,235 dalam setiap satuannya. Nilai koefisien ini signifikan karena nilai $t_{\text {hitung }}$ sebesar 3,650> $t_{\text {tabel }}$ sebesar 2,0141 dengan nilai signifikan $0,001<a=0,05$, berarti $\mathrm{H}_{\mathrm{a}}$ diterima dan $\mathrm{H}_{\mathrm{o}}$ ditolak.

Sumber modal tidak berpengaruh signifikan terhadap motivasi wanita untuk berwirausaha di Kabupaten Pasaman Barat, hal ini dibuktikan dimana pada nilai dari $\mathrm{x}^{2}$ hitung loglikelihood ratio adalah 0.563703 sedangkan nilai $\mathrm{x}^{2}$ tabel adalah sebesar 3,841 , dengan a $=0,05$ dengan df 1 (sebesar variabel yang dihilangkan) dimana menunjukan $\mathrm{x}^{2}$ hitung $<\mathrm{x}_{\text {tabel }}^{2}$ dengan demikian berarti menerima $\mathrm{H}_{\mathrm{O}}$ yang berati menerima menghilangkan variabel sumber modal.

Pemberdayaan diri berpengaruh positif dan signifikan terhadap motivasi 


\section{JURNAL \\ HORIZON}

PENDIDIKAN
JURNAL HORIZON PENDIDIKAN

Publish by: Library of STKIP PGRI Sumatera Barat

E-ISSN : 2775-5770

Vol. 1 No. 2 (Mei 2021) (333-344) wanita untuk berwirausaha di

Kabupaten Pasaman Barat, hal ini

dibuktikan dengan nilai Koefisien

regresi variabel teman sebaya sebesar

0,464 Hal ini berarti adanya apabila

nilai variabel pemberdayaan diri meningkat sebesar satu satuan maka motivasi wanita untuk berwirausaha akan meningkat sebesar 0,464 dalam setiap satuannya, Nilai koefisien ini signifikan karena nilai $t_{\text {hitung }}$ sebesar $4,069>t_{\text {tabel }}$ sebesar 2,0141 dengan nilai signifikan $0,000 \mathrm{a}=0,05$, berarti $\mathrm{H}_{\mathrm{a}}$ diterima dan $\mathrm{H}_{\mathrm{o}}$ ditolak.

Pendidikan tidak berpengaruh signifikan terhadap motivasi wanita untuk berwirausaha di Kabupaten Pasaman Barat, hal ini dibuktikan dengan nilai dari $\mathrm{x}^{2}$ hitung likelihood ratio adalah sebesar 0.312201 sedangkan nilai $\mathrm{x}^{2}$ tabel adalah sebesar 3,841 , dengan a $=0,05$ dengan df 1 (sebesar variabel yang dihilangkan) dimana menunjukan $x^{2}$ hitung $<x_{\text {tabel }}^{2}$ dengan demikian berarti menerima $\mathrm{H}_{\mathrm{O}}$ yang berati menerima menghilangkan variabel pendidikan.

Minat berpengaruh positif dan signifikan terhadap motivasi wanita untuk berwirausaha di Kabupaten Pasaman Barat, hal ini dibuktikan dengan nilai Koefisien regresi variabel minat sebesar 0,308 yang bertanda positif. Hal ini berarti adanya pengaruh positif minat terhadap motivasi wanita untuk berwirausaha di Kabupaten Pasaman Barat,, apabila nilai variabel minat meningkat sebesar satu satuan maka motivasi wanita untuk berwirausaha, akan meningkat sebesar 0,308 dalam setiap satuannya. Nilai koefisien ini signifikan karena nilai $t_{\text {hitung }}$ sebesar $3,254>t_{\text {tabel }}$ sebesar 2,0141 dengan nilai signifikan 0,002 < $\mathrm{a}=0,05$, berarti $\mathrm{H}_{\mathrm{a}}$ diterima dan $\mathrm{H}_{\mathrm{o}}$ ditolak.

Pengaruh Peran Suami, Sumber Modal, Pemberdayaan diri, Pendidikan dan Minat Terhadap Motivasi Wanita Untuk Berwirausaha di Kabupaten Pasaman Barat, dimana di perolah nilai hasil penelitian yang menyatakan bahwa dengan hasil penelitian yang menyatakan bahwa nilai FHitung 25,350 > FTabel 2,40 dan nilai signifikan $0,000<=$

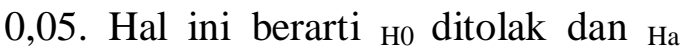
diterima berarti secara bersama-sama berpengaruh variabel independent 
HORRZON

PENDIDIKAN
JURNAL HORIZON PENDIDIKAN

Publish by: Library of STKIP PGRI Sumatera Barat

E-ISSN : 2775-5770

Vol. 1 No. 2 (Mei 2021) (333-344) terhadap variabel dependent. Dari hasil analisis koefisien determinasi yang dilakukan diperoleh nilai Rsquere sebesar 0,623 yang artinya $62,3 \%$ perubahan pada variabel dependent (motivasi) dapat dijelaskan oleh variabel independen (peran suami, sumber modal, pemberdayaan diri, pendidikan, dan minat) sedangkan sisanya sebesar $37,7 \%$ dipengaruhi oleh variabel lain yang tidak termasuk dalam penelitian ini.

\section{DAFTAR PUSTAKA}

Alma, Buchori. (2005). Kewirausahaan. Bandung: Alfabeta.

Arikunto. (2010). Prosedur Penelitian: Suatu Pendekatan Praktik. Jakarta: Rineka Cipta.

Arikunto, S. (2010). Prosedur Penelitian: Suatu Pendekatan Praktik. Edisi Revisi. Jakarta: Rineka Cipta.

Pristiana, Ulfi, Amiartuti Kusumaningtyas, and Siti Mujanah. (2009). Faktor-Faktor Yang Mempengaruhi Pengambilan Keputusan Wanita Berwirausaha di Kota Surabaya. Jurnal Riset Ekonomi dan Bisnis 9(1):52-65.

Relawati. (2011). Pemberdayaan Perempuan Pembangunan Indonesia. Jakarta.

Rizal, M., D. Setianingsih, and R. Chandra. (2016). Faktor-Faktor
Yang Mempengaruhi Wanita Berwirausaha (Studi Kasus Di Kota Langsa). Jurnal Manajemen Dan Keuangan Unsam 5(2):52534.

Suryana. (2006). Kewirausahaan: Kiat dan Proses Menuju Sukses. Jakarta: Salemba Empat.

344 | Fitria Devi, Lovelly Dwinda Dahen, Jimi Ronald 1/ JHP, Vol. 1 No. 2, 2021 